\title{
Marrying for a Future: Transnational Sri Lankan Tamil Marriages in the Shadow of War by Sidharthan Maunaguru (Seattle: University of Washington Press, 2019)
}

\author{
Reviewed by Sivamohan Sumathy \\ Department of English, Faculty of Arts, University of Peradeniya, Peradeniya, Sri Lanka.
}

Marrying for a Future is an engaging and deeply moving ethnographic account of the life of marriage in transition of Sri Lankan Tamils in the time of war and after. Calling into question identities that fix one to place, such as native and diaspora, Maunaguru brings fresh thinking into the study of movement and mobility, the certainties of place and identity and most of all, life lived fully as an in-between. It is an evocative exploration, at times excruciatingly painful in its understated pronouncements about structural hierarchies, hegemonies, borders and subject formation in a Sri Lankan marriage.

The study uses three key terms, drawing upon Turner, Povinelli and Deleuze; the place of an in-between, uncertainty and potentiality. Potentiality is the non-linear actualisation of the in-between status of experience and existence of the subjects and is characterised by an uncertainty that textures all their quests for a future. The "in-between" is not just an in-between in the movement from one place to another; it is its own place, and as the author says, in an invocation of Povinelli, its potentiality. This potentiality is not teleological and is both lost and found in the separation of the couple before marriage, one in Sri Lanka, and the other in a western country, and after marriage, both imagining a place elsewhere. There is constant deferral of this place, for even after the wedding has taken place, a couple has to wait for the endless, circuitous, gruelling and destructive immigration processes that govern (re)unification. It takes as its points of departure the migratory patterns of Sri Lankan Tamils, particularly from the north and east and more specifically from the northern city Jaffna, predominantly to the west and to India, from the 1980's onwards. With the escalation of war and its cruel intensities, where life was not only unbearable, but was experienced by everybody as a personal targeting of the Tamil polity, many felt that they indeed had no future in the country. But Marrying for a Future does not place marriage, migrations, within epistemological teleologies. One does not marry to get out of the country, instrumentalising it for an end goal that can be envisioned as a certain future. Rather, the community, in the in-between of transition, embodies a practice of uncertainty. For the people, every certain step toward the normative, like marriage (heterosexual marriage), is a step toward further uncertainty, and every step toward ensuring continuity, like marriage customs for instance, is a further imbrication in uncertainty; it takes in an uncertain place, in an uncertain time, moving toward an uncertain future. However, this uncertainty indicates a certain knowing, a knowing about what it is to be Sri Lankan and to be Sri Lankan Tamil.

The watershed of 1983 is the point of departure in time. Almost a million Tamils from Sri Lanka, most from the Jaffna peninsula, are settled in varying statuses of immigration in the west and in India. The migrants move within Sri Lanka and outward and therefore, the entire geography of the globe, at least those many and varied criss-crossing lines traced by the travels of these refugees and migrants, are points of transit, including

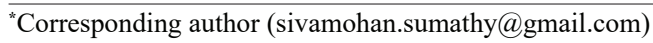

This article is published under the Creative Commons CC-BY-ND License (http://creativecommons.org/licenses/ by-nd/4.0/). This license permits use, distribution and reproduction, commercial and non-commercial, provided that the original work is properly cited and is not changed anyway. 
the places that this society inhabits in Sri Lanka itself. In such a rendering, war itself is a transfiguration of social relations, and the everyday. But it is not just war, but everything that ensues from it, textures it and even engenders it, is a transfiguration of life.

Jaffna Tamils, most significantly, Vellala Tamils, from 1983 onwards have sought to escape the conditions of war through marriage. Families embarked on this project of marrying off their daughter, son, nephew, niece, to another Sri Lankan (Tamil of course) who has somehow found domicile in a western country. Apart from the involvement of immediate family members and the couples themselves, the marriages are usually arranged and organised by an assemblage of persons, brokers who have modernised themselves with data bases and fancy epithets, photographers, officiating priests, owners of lodges, hotels and wedding parlours, immigration officials and finally and interestingly, para legal Sri Lankan intermediaries in Canada, who help the newly-weds in cases where the immigration has refused the spouse entry into the country. Semiotically and epistemically, documents, photographs, data bases and immigration systems become the signposts of a marriage. Marriage is reinvented as necessary and necessarily uncertain and is seen to be in stasis in no place. Navigating a multitude of hegemonic forces, the family and the young couple themselves, seek an escape from an oppressive situation, through recourse to one of the most hegemonic of all structures; a structure that is designed to bring stability, cohesion to the family and the community; but only succeeding in further fragmenting the community, and dispersing it, in far flung places, and leaving the couple to face a future that is steeped in uncertainty.

The book is an ethnography and in that it strives to pin down a few places of transit; Colombo, Chennai and Toronto, a place that is home to more than half a million Sri Lankan Tamils. It begins with an "intention," that of a father, a mother, an aunt, or a well-wisher who would look for a bride/groom abroad. In the assemblage of interlocking figures, one that stands out is the marriage broker. These marriage brokers are not the "traditional" ones, whose standing in society were at the best of times, dubious, and often related to their caste functioning in Jaffna society. These new-fangled brokers could be retired government officers, middle to lower middle-class parents, who had acquired knowledge and understanding of the process in their endeavour to make similar marriages for their own daughters, people who need a livelihood in the war economy, but want to do it in as an act of service. Within the dispersal of community, tested methods of inquiring after the suitability of a particular groom are irrelevant. New and knowing modes of inquiry need to be at hand. One of the important epistemic units of knowing of this new set of brokers is the varied and ever-changing immigration conditions of the countries of destination. The success of a spouse's admission to the adoptive country is dependent on the couple's fulfilling complicated immigration conditions governing long distance marriages of this kind; they go far beyond anything set down in writing. There is much that is left unsaid in these assessments; the couple and the spouse applying for a reunion visa have to prove the "authenticity" of the marriage that goes far beyond the credibility of the official marriage certificate. The new professional broker of the transit place is a repository of this complicated corpus of rules and is the nexus between the family in Sri Lanka, the spouses to be, and the states in question, including the Sri Lankan state. The broker looks to the viability of the marriage, not only in terms of family and spousal suitability, important caste affinities and occupational, educational, and other preferences of the couple themselves, but also into whether the couple's status would conform to easy admission to the adoptive country, via immigration norms.

The marrying parties are from Sri Lanka and a western country, Canada. But the marriage takes place in Chennai for a complex of reasons. Chennai, the metropolitan centre of South India, is a Tamil speaking region in India and is home to a few tens of thousands of Sri Lankan Tamils displaced there. But it is the place of meeting and reimagining of a common future for Sri Lankan Tamils. It is the place of a Sri Lankan marriage, where marriages arranged between a bride in Sri Lanka and bridegroom in Toronto encounter each other, their families, tie the tali and hope for a life together. The couples with their entourage of families and friends travel to Chennai. The broker if he is stationed in Chennai, like one of the brokers in the book, may offer a package to the couple and the families; lodgings, parlour, advice on shopping place and places to sight see. He also helps one hire a Sri Lankan Priest to officiate the ceremony and a Sri Lankan photographer. He may also help one with finding Sri Lankan guests, for guests are important not just for documentary evidence of a marriage, but also for the affect that a wedding produces, meeting with one's family, rekindling memories of a past, evidencing certainty, stability, and the reconfiguration of place.

It is not just the broker who has acquired a new significance, like that of a travel agent's new role in these travels, but also the photographer and the Iyar, the officiating priest. A telling instance of the critical roles played by the photographer and the priest is demonstrated in the story where the appointed Sri Lankan priest is unable to officiate and an Indian Iyar steps in. The Sri Lankan photographer and the priest have 
rather pointed disagreements over how the ceremony is conducted; the family of the bride, too, is anxious about the way the Indian Iyar hurries through the ceremony. They are anxious about their daughter's future, worrying that if the wedding is not conducted properly, it may not bode well for her; and while their fears are about the stars and the planets being in the right place, there is a sharp materiality to their concerns too. Immigration authorities have their own understanding of how a Sri Lankan marriage is conducted and this understanding guides the conduct of a ceremony in this transit place.

The photograph and the photographic album become the technologies of power in this fashioning of Sri Lankan subjecthood. The photographer becomes the archivist and the disseminator of knowledge, of the customs of a (dubious) past, and the requirements of a future - the immigration complex. The ceremony then becomes accentuated in the photographer's focus on the ritual rather than on the couple or the families of the couple. Rituals are captured in close ups and in sharp relief, and are repeated until the photographer gets it right. In this act the priest and the photographer collude. A Sri Lankan marriage has so many impositions from so many quarters, fulfil so many expectations, that vary from the familial to the state and to the transnational. It is a potentiality that has no end, only a deferral of its passage to certainty. Fragments of documents and fragments of memory, a notion Maunaguru borrows from Veena Das, and uses creatively, plays into this understanding that life is reconfigured in its potentiality. The fragment works its way into the everyday, as practice and as desire for a future.

The photograph of a marriage in Chennai or elsewhere has to attest to the presence of guests. Hence, the inviting of guests, one may say, and if there are going to be guests, why not Sri Lankan guests. The marrying families through the broker or another mediator invite Sri Lankan residents in neighbouring places to the wedding ceremony. This maybe to fulfil an immigration requirement, but as Maunaguru argues, what makes an overall and fragmented sense of place is the affect of being surrounded by witnesses, and in this instance, critically, Sri Lankans, who would bear witness of it to the Canadian immigration, also speak about it to others; and be a part of the making of a Sri Lankan marriage.

Tradition is invented says Hobsbawm and it is nowhere more at play than in the invention of it by multiple mediators of identity making, not the least among them, Immigration Authorities of western countries. The navigation of multiple hegemonies is overseen and overdetermined by the eye of an overseeing immigration officer. Unlike the photographer, the priest or the broker, who is personally invested in the lives of the families and the bride and bride groom, and whose investment in the marriages is set within the structure of place, the authority figure of the immigration officer invites no such endearing affective identification. The officer is officialdom itself. This makes it all the more frightening that the officer has so much power in judging and laying claim to knowledge about how a Sri Lankan marriage should be. One of the brides makes an application for entry into Canada, following her marriage to a Canadian resident, and has it turned down on the grounds that her mother and some other family members did not follow her to the wedding ceremony in Chennai; that the bride and bridegroom did not seem intimate enough; that an older relative did not play a prominent role in the wedding ceremony. The bride at the time of the book's publication is still waiting for her visa. In-betweeness is carried to another point here, to the borders of Canada itself, where the resident Sri Lankan and the spouse desiring entry, become the "foreign-insider" and the "foreign-outsider," as both encounter and battle a series of immigration and legal authorisations, subjugating the state itself to an anxiety about its purview and its certain borders. The para legal Sri Lankan lawyer lurking in the wings who mediates between the couple and the Canadian Englishspeaking lawyer and the judiciary, is another in-between and shadowy figure here.

An interesting foray into the colonial court room and its arbitration on the validity of customary marriages, among Sri Lankan Tamils and in other colonial places, provides the background to the immigration authorities' overseeing eye, arbitrating on the validity of a marriage. There are continuities and discontinuities between the colonial court rooms, arbitrating on customary marriages and trying to negotiate with their validity and the immigration officers' practice of passing judgement on the authenticity of a Sri Lankan marriage. The judges in the colonial court room used the principle of intention and the presence of a public at a wedding in their judgement, assessing the authenticity of a marriage. The immigration officer, whose assessment of a marriage, has no legal validity, nevertheless, turns a colonial gaze upon the marriage, arbitrating on it, in the new configuration of authority and power in the postcolony. Tamil marriages in Sri Lanka are steeped in a tradition brought together through the confluence of the colonial legality and customary practices. Like the colonial court room, the immigration court room too makes its judgement, on the basis of what it understands to be the intention of the couple after marriage; Was the wedding customary enough? Would they stay together after marriage? Canadian immigration insists on the conduct of a customary wedding, with fan fare, the presence of a public, and other accoutrements considered to be a part 
of a customary marriage, suspending their purported adherence to individual choice and liberal values. In this, the Canadian immigration and the immigration court can be seen as more conformist than the colonial courts, which accepted heterogenous practices in customary marriages, accommodating variations in caste and regional practices.

There are certain questions I am prompted to ask in my review, touching upon the hegemonies of community traced in all places, even in in-betweeness. But I too fancy an elsewhere to get to my point. In my continuing engagement with the enduring life of the nation, theoretically and as a dynamic process, in Sri Lanka and elsewhere, I see Marrying for a Future as a critical encounter with the renewed notions of nation making in the transnational place. For Maunaguru this place cannot be named, not even as transnational, for the meaning of nation disintegrates even within its own making. But I do want him to speak of the hegemonies more, for they are scattered about everywhere as faultlines of caste, class and gender shaping the encounters in the transit place.

In a slight digression into semiotics, Maunaguru takes on Barthes's supposed view that the photograph is selfevident of the real and therefore, cannot be penetrated. As a semiotician of sorts, I am compelled to assert here that Barthes's understanding of "evidence" is much misunderstood by many; in other words, for Barthes, the authenticity of the photograph is a constructed one. Barthes looks for a history beyond what the photograph offers to us as the real, but that history is simultaneously thick and ideological. It is a semiotic of the political. A more careful deployment of Barthes's history that is ideological and semiotic might have led Maunaguru to an unlocking of the mystique of the photograph and to get to its referenced history that is not just about Immigration Authorities, but of the intertextual of the international the history of the nation: the fragment that is understood as a whole in the conceptualisation of history, a history of the nation. One wonders about the unstated in-betweeness of the documented place of these Vellala marriages and its gendered potentialities that have given so much life to the nation in the war years in the place of transit.

This is a question I ask in my own work, specifically, underlining the availability and unavailability of the nation in these transnational quests (Sumathy, 2005). The question of gender and its proximity to women has to be asked anthropologically and politically. Women are present everywhere but are present as absences (except in a few rare instances, where women appear in court documents as agents) in a world full of immigration offices, judges, brokers, photographers, fathers and priests, all seemingly male. Such an undertaking compels one to ask for a nuanced, gendered understanding of the complexities of the in-between and its reconfiguration of life.

In the making of the Sri Lankan marriage and its tragic consequences for at least some of its participants, the figure of the immigration officer, loses their humanity and their capacity to change, and to occupy the in-between place. The potentialities that the marriages propose often leave us with a profound sense of sadness. I think of the account of a bride who is rejected by the bridegroom for reasons unstated, after the bridal and the grooms' parties have made their way to Chennai for the wedding. In response, the broker persuades the bridegroom's party to go ahead with the wedding. Here, potentiality itself becomes tragic in its making. The now-wife waits for the invitation by her new husband to begin the reunification visa process.

Yet, one sees hope in the transfiguration of life in the transit place. I close this review with a deeply touching scene that is both sad and laced with a piquant hope for the future: a garden of trees greets the beholder in the backyard of a "marriage facilitator" (broker), in Chennai - trees planted by couples on their wedding day, as is customary in a Jaffna Tamil (Vellala) wedding, where the couple plant a tree in their own garden. In our story, the trees are left behind in the broker's back yard. They grow, displaced in the in-between place of a homely backyard of a Sri Lankan broker of a Sri Lankan Marriage. They are silent witnesses and bearers of a potential future for humanity.

\section{REFERENCES}

Sumathy, S. (2005) The Middle Passage: migration and displacement of Sri Lankan Tamil women of the diaspora, Socio-Legal Review, 1(1), pp: 11-29. 